\title{
Zn Electrodeposition of Titanium Dioxide for the Application of Dye Sensitized Solar Cell (DSSC) with Extracts of Natural Dyes That Were Co-pigmented with Salicylic Acid

\author{
Hardeli Hardeli ${ }^{*}$, Hary Sanjaya ${ }^{1}$, Nurul Fadhilah A ${ }^{1}$, Lasmi $\mathrm{Y}^{1}$
}

\author{
${ }^{1}$ Chemistry Department, Faculty of Mathematics and Science, Universitas Negeri Padang, Padang, Indonesia \\ *Corresponding author.Email: tmarten03@gmail.com
}

\begin{abstract}
Dye Sensitizer Solar Cell (DSSC) is a dye- based solar cell which is an alternative to meet energy needs, where these cells will convert sunlight energy into electrical energy. This study aims to produce DSSC using Indium Tin Oxide (ITO) glass as a substrate and extract of red grape skin (Vitis Vinifera), jengkol skin extract (Pithecellobium jiringa), resident fruit (Melastoma malabathricum L), and mangosteen peel (Garcinia Mangostana) L) as a dye sensitizer. The semiconductor material used is Titanium dioxide (TiO2), because titanium dioxide has a wide band gap, is inert, harmless and also has a wide surface. The research began with the preparation of ITO glass which was carried out by a doctor blade method coated with $\mathrm{TiO} 2$ paste, after being coated the glass was heated on a hot plate at $100^{\circ} \mathrm{C}$ for 30 minutes, and electrodeposition of $\mathrm{Zn}$ metal, after that the ITO glass was heated to the furnace and dropped by dyes. In other ITO glass the conductive part is coated with carbon from heating on a candle, after which solar cells are tested by assembling the glass like a sandwich, and dropped by an electrolyte solution. The dye used is characterized by using UV-Vis and FTIR. The results of XRD analysis showed that there was a decrease in the size of $\mathrm{TiO} 2$ crystals and that $\mathrm{ZnSO} 4$ was still present in $\mathrm{TiO} 2$. The decrease in crystal size will cause an increase in the surface area of $\mathrm{TiO} 2$ thereby increasing DSSC efficiency. The efficiency of DSSC that uses Zn electrodeposition on TiO2 ( $\mathrm{Zn}-$ $\mathrm{TiO} 2$ ) has increased compared to DSSC using pure $\mathrm{TiO} 2$, from $0.8 \%$ to $4.14 \%$ at $1 \mathrm{~V}$ electrodeposition voltage. This increase occurs because a barrier layer of the process of recombination of electrons with electrolytes and an increase in the surface area of $\mathrm{TiO} 2$. The optimum voltage and time of electrodeposition of $\mathrm{Zn}$ on $\mathrm{TiO} 2$ are $1 \mathrm{~V}$ and 15 seconds with the resulting DSSC efficiency of $6.00 \%$. DSSC performance produced with TiO2- $\mathrm{Zn}$ layer and co-pigmented pigments were $1.8062 \%$ jengkol peel, $4.40 \%$ resident fruit, $3.8039 \%$ mangosteen peel, and $4.812 \%$ grape skin. The highest efficiency was obtained on DSSC by Zn electrodeposition in $\mathrm{TiO} 2$ layer using grape skin as a source of dyes.

Keywords: DSSC, red grapes, jengkol skin, resident fruit, mangosteen peel, Zn electroplating.
\end{abstract}

\section{INTRODUCTION}

In general, an increase in energy demand is closely related to growing economic activity and increasing population (Asy'ari, Jatmiko, \& Angga, 2012). Energy that is commonly used comes from fossil energy, with the depletion of fossil energy sources there is a shift from the use of non-renewable energy sources to renewable energy sources. Renewable energy sources include solar cells, wind, biomass and hydro power (Septina, Fajarisandi, \& Aditia, 2007). In Indonesia, the use of energy through solar cells is the most potential alternative of many other renewable energy sources because it is located on the equator which tends to receive perpendicular radiation compared to other regions on the surface of the earth. The developed solar cell is a Dye Sensitized Solar Cell (DSSC).

DSSC is a good source of energy developed for the future because of its relatively low production costs. In contrast to conventional solar cells where all processes involve silicon material itself, in dye-sensitized solar cells (DSSC) the absorption of light and the separation of electrical charges occur in separate processes. Light absorption is carried out by dye molecules and charge separation by nanocrystalline inorganic semiconductors which have a wide band gap (Septina, 2007). 
One semiconductor that has a wide band gap and is often used is Titanium Dioxide (TiO2). $\mathrm{TiO} 2$ is used because it is inert, harmless, inexpensive semiconductor, and has good optical characteristics. However, for applications in dye- sensitized solar cells (DSSC), TiO2 must have a broad surface so that the dye is absorbed more so that it will increase photon flow. Besides the use of dye material that is able to absorb a wide spectrum of light and is compatible with the $\mathrm{TiO} 2$ energy band is also an important characteristic (Septina, 2007). $\mathrm{TiO} 2$ is an n-type semiconductor and has a fairly large band gap of around $3.2 \mathrm{eV}$. The lowest level of the $\mathrm{TiO} 2$ conduction band is also below the Low Unoccupied Molecular Orbital (LUMO) level, so that electrons that are excited at the LUMO level are easily transferred to the $\mathrm{TiO} 2$ conduction band (Hidayat, Rokhmat, \& Qurthobi, 2014). The price of $\mathrm{TiO} 2$ is also relatively cheap and does not cause harmful effects on health and the environment, but its absorption of sunlight is still low.

The thin layer of $\mathrm{TiO} 2$ semiconductor is only able to absorb $5 \%$ of the spectrum of sunlight from the entire spectrum of sunlight in the UV spectrum $(200 \mathrm{~nm}-400$ $\mathrm{nm}$ ) for that the use of dyes is very important. Dyes used in DSSC must have good absorption in visible light in order to obtain optimal solar energy conversion from DSSC solar cells (Sutrisno, 2010). Anthocyanin is one of the natural dyes that has attracted attention to be developed as a sensitizer in DSSC. The use of anthocyanin as a dye can expand the absorption area so that it affects the efficiency. Anthocyanin is a natural dye which is easily oxidized / damaged.

One way to increase the stability of anthocyanin is by copigmentation. Anthocyanin copigmentation is the interaction of anthocyanin in the form of a flavilium cation with a copigment which can be in the form of metals or organic compounds (Lestario \& Andini, 2016). Anthocyanin can form a more complex compound when interacting with other organic compounds through the copigmentation reaction. Anthocyanin copigmentation causes a batochromic effect, which is a shift in absorption of the maximum wavelength to a longer wavelength region in other words expanding the absorption area.

The low efficiency of DSSC using natural dyes is due to the recombination of injected electrons and redox pairs in electrolytes (Mozaffari, Ranjbar, Kouhestanian, Salar Amoli, \& Armanmehr, 2015). In this study metal electrodeposition was carried out to reduce the process of electron recombination and improve DSSC performance using natural dyes.

Metal electrodeposition is a way to form a barrier layer between electrolytes and $\mathrm{TiO} 2$, thereby reducing the process of electron recombination due to the difference in band gap between $\mathrm{TiO} 2$ and small electrolytes (Kang, Kim, Kim, Kim, \& Sung, 2007). In a study conducted by Prasetyowati (2012) iron metal was inserted into titanium dioxide using the electroplating method and the effect was observed on DSSC, DSSC efficiency is known to increase from $0.001 \%$ to $0.2 \%$ after using $\mathrm{TiO} 2$ with iron metal insertion. This study shows that metal insertion has a major influence on the performance of DSSC produced. Electrodeposition of $\mathrm{Zn}$ metal on $\mathrm{TiO} 2$ has been carried out in a study by John K et al (2016), namely electrodeposition of $\mathrm{Zn}$ on $\mathrm{TiO} 2$ nanotubes to increase DSSC efficiency. Based on the research of John $\mathrm{K}$ et al (2016), the electrodeposition process has been carried out and produces DSSC efficiency 2 times greater than DSSC without metal electrodeposition.

In this research electrodeposition of $\mathrm{Zn}$ metal on $\mathrm{TiO} 2$ will be carried out with variations in voltage and electrodeposition time. Electrodeposition time and voltage will affect the efficiency of the DSSC produced (Nurfithri et al., 2016; Prasetyowati, 2012). Increasing time and voltage will increase the amount of $\mathrm{Zn}$ on the $\mathrm{TiO} 2$ surface, so that $\mathrm{Zn}$ electrodeposition is carried out with variations in time and voltage to determine the optimum conditions for $\mathrm{Zn}$ electrodeposition which increases the efficiency of the DSSC produced.

The application of $\mathrm{Zn}$ electrodeposition on $\mathrm{TiO} 2$ to DSSC was only carried out on DSSC without involving dyes. This research was conducted by observing the influence of $\mathrm{Zn}$ electrodeposition on DSSC performance with dyes from jengkol skin (Pithecellobium jiringa B.), senduduk fruit (Melastoma malabathricum L.), mangosteen peel (Garcinia mangostana L.), and red grape skin (Peelecellobium jiringa B.), senduduk fruit (Melastoma malabathricum L.), mangosteen peel (Garcinia mangostana L.), and red grape skin (Peelecellobium jiringa B.) Vitis venifera) which is copigmented with salicylic acid. These materials are organic materials that can be used as dye molecules in DSSC because they contain anthocyanidin dyes. Copigmentation is a procedure to increase the intensity and absorption of dyes in sunlight. This study aims to determine the effect of $\mathrm{Zn}$ electrodeposition on $\mathrm{TiO} 2$ on DSSC performance with various copigmented dyes.

\section{MATERIALS AND METHODS}

\subsection{Preparation of the pigmented pigments}

Preparation of dyes was carried out by taking 40 grams of jengkol fruit skin, resident fruit, mangosteen rind and grape skin, mashed, macerated with $50 \mathrm{~mL} 96 \%$ ethanol and $10 \mathrm{~mL} 1 \mathrm{M} \mathrm{HCl}$ for 24 hours. The filtrate is filtered and evaporated with a rotary evaporator until a solid dye is obtained. The extract of $1 \mathrm{~mL}$ was diluted with a $\mathrm{pH}$ buffer of 4.5 and 1 to a volume of $10 \mathrm{~mL}$. The extract was then measured for its absorbance by using electronics at wavelengths of $510 \mathrm{~nm}$ and $700 \mathrm{~nm}$ to determine the total amount of anthocyanin in the dye extract and the amount of salicylic acid used. 


\subsection{ITO glass preparation}

ITO glass is cut with a size of $1.25 \mathrm{~cm} \mathrm{x} 1.25 \mathrm{~cm}$ and sanded the edges until smooth. ITO glass is put into a beaker containing $200 \mathrm{~mL}$ of $70 \%$ alcohol. Chemical beaker containing ITO glass and alcohol is put into an ultrasonic cleaner. The ultrasonic cleaner is set to 60 minutes for the cleaning process. After 60 minutes the ITO glass was dried. This process aims to remove material that will interfere with the $\mathrm{TiO} 2$ coating process on ITO glass (Kumara \& Prajitno, 2012).

\subsection{Making TiO2 paste}

1 gram polyvinyl alcohol (PVA) is dissolved in $10 \mathrm{ml}$ of distilled water, the solution is stirred while heated on a hot plate at $80^{\circ} \mathrm{C}$ until a PVA suspension is formed. PVA solution is put into a mortar containing 1 gram of Titanium dioxide (degussa P-25). The mixture is crushed until a good paste is formed (Prasetyowati, 2017).

\subsection{TiO2 coating on the ITO glass}

In ITO that has been cut to a size of $1.25 \times 1.25 \mathrm{~cm}$, an area where $\mathrm{TiO} 2$ is formed is deposited with the help of Scotch tape on the conductive glass so that an area of $1 \mathrm{x} 1$ $\mathrm{cm}$ is formed. $\mathrm{TiO} 2$ paste was deposited with $\mathrm{TiO} 2$ paste on the surface of ITO glass which had been given Scotch tape using the doctor blade method, then dried on a hot plate with a temperature of $100^{\circ} \mathrm{C}$ (Prasetyowati, 2017).

\subsection{Electrodeposition of $\mathrm{Zn}$ on $\mathrm{TiO} 2$}

The $\mathrm{Zn}$ electrodeposition process uses 2 electrodes, namely $\mathrm{TiO} 2$ working electrodes and zinc plate anodes with ZnSO4 0.1 M electrolytes (John K, Naduvath, Mallick, Pledger, \& Philip, 2016). After the electrodeposition process is complete, the layer is dried in an oven at $100^{\circ} \mathrm{C}$ for 10 minutes (Prasetyowati, 2012).

\subsection{Characterization of $\mathrm{TiO} 2$ and $\mathrm{Zn}$-TiO2 layers on the Glass Surface}

The characterization of $\mathrm{TiO} 2$ and $\mathrm{Zn}$-TiO2 layers was carried out with XRD which was carried out in the Panalitycal X'Pert Pro MPD Research Laboratory Laboratory, equipped with X'Celerator Fast Detector. Tests were carried out before $\mathrm{Zn}$ electrodeposition on $\mathrm{TiO} 2$, and after $\mathrm{Zn}$ electrodeposition.

\subsection{Semi-solid electrolyte preparation}

Semipadate electrolytes were prepared by dissolving 0.498 gr KI and 0.076 gr $\mathrm{I} 2$ in $6 \mathrm{~mL}$ acetonitrile in two different beakers. KI and $\mathrm{I} 2$ solutions are mixed and stirred until homogeneous. $2.4 \mathrm{~g}$ of PEG was added to the mixture and stirred to form a gel (Damayanti et al .; 2015).

\subsection{Electrode counter preparation}

Counter Preparation Carbon electrodes are prepared using wax to form a carbon layer. The carbon is superimposed on ITO in its conductive part by holding it close to a burning candle until a thick carbon layer is formed on the surface of the ITO glass. The carbon layer formed is then formed according to the size of $1 \mathrm{~cm} \mathrm{x} 1 \mathrm{~cm}$ (Chadijah, Dahlan, \& Harmadi, 2018).

\subsection{Fabrication of Solar Cells}

After each component of the DSSC is fabricated, fabrication is carried out to form solar cells. The $\mathrm{Zn}-\mathrm{TiO} 2$ layer deposited on the ITO glass surface is immersed in a dye solution for 30 minutes then the $\mathrm{TiO} 2$ layer (Maulina, 2014). The $\mathrm{Zn}-\mathrm{TiO} 2$ layer that has been soaked in dyes is dried with tissue and covered with a counter electrode. The electrolyte solution is then dropped about 2 drops into the space between the two electrodes. The solar cell is then tested using a multimeter.

\subsection{Testing of Solar Cell Electric Current}

The solar cells that have been assembled are tested, which is a direct test of the measured voltage and current of a solar cell using a digital multimeter. The light source used is light from UV lamps with 24 watts of power. The obtained current and voltage values are calculated to measure the efficiency value of the assembled DSSC.

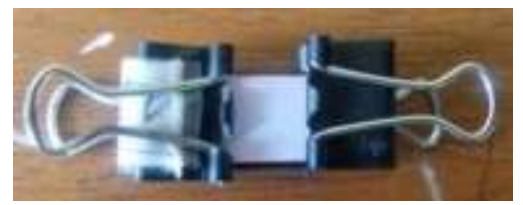

Figure 1. DSSC assembled

\section{RESULT AND DISCUSSION}

\subsection{Preparation of DSSC using Titanium Dielectrodeposition $\mathrm{Zn}$}

ITO glass that has been coated with $\mathrm{TiO} 2$ is then carried out by $\mathrm{Zn}$ electrodeposition process with voltage and time variations according to Table 2 . Voltage and time variations are carried out to determine the optimum electrodeposition conditions that produce DSSC with the highest efficiency. Electrodeposition is a process for coating a chemical species to the cathode through an electrolysis cell. In this research, $\mathrm{Zn}$ electrodeposition on the surface of titanium dioxide to modify titanium dioxide and form a barrier layer between $\mathrm{TiO} 2$, Dyes, and electrolytes to reduce the recombination of injected electrons into DSSC. The Zn electrodeposition process was carried out with an electrochemical cell using $0.1 \mathrm{M} \mathrm{ZnSO} 4$ electrolyte, cathode layer $\mathrm{TiO} 2$ on ITO glass and zinc plate anode 
according to the figure. The reactions that occur in the $\mathrm{Zn}$ electrodeposition process are:

Cathode: $\mathrm{Zn}_{(\text {aq })}^{2+}+2 e^{-} \rightarrow Z n_{(s)}$ (on the surface of $\left.\mathrm{TiO}_{2}\right)$

Anode $: Z n_{(s)} \rightarrow Z n_{(a q)}^{2+}+2 e^{-}$

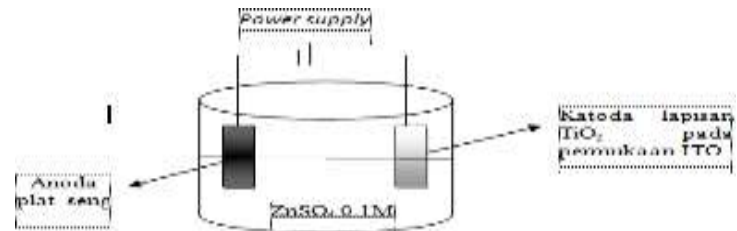

Figure 2. Schematic electrodeposition of $\mathrm{Cu}$ on $\mathrm{TiO} 2$

\subsection{Characterization of $\mathrm{Zn}$ Electrodeposition Layer on TiO2 (Zn-TiO2)}

XRD analysis was performed on the surface of $\mathrm{TiO} \neg 2$ without $\mathrm{Zn}$ electrodeposition and $\mathrm{TiO} 2$ with $\mathrm{Zn}$ electrodeposition. The purpose of XRD analysis is to determine the effect of $\mathrm{Zn}$ electrodeposition on the size and structure of surface crystals of $\mathrm{TiO} 2$ that have been coated on ITO glass. The size of $\mathrm{TiO} 2$ crystals will affect the surface area to absorb dyes. The crystal structure will affect the electron transfer that occurs in titanium dioxide. The diffractogram results of XRD characterization of $\mathrm{TiO} 2$ layers without $\mathrm{Zn}$ electrodeposition and with $\mathrm{Zn}$ electrodeposition can be seen in Figure 3. The XRD analysis results are interpreted with standard data from COD (Crystallography Open Database) data can be observed in Tables 1 and 2. The analysis results for $\mathrm{TiO} 2$ with $\mathrm{Zn}$ electrodeposition shows some peaks that are suitable for the metal peak of $\mathrm{Zn}$.

Crystal sizes are calculated using FWHM data (full width at half-maximum) based on the Scherrer equation at various peaks. The crystal size of $\mathrm{TiO} 2$ without $\mathrm{Zn}$ electrodeposition is $63.62 \mathrm{~nm}$ with a FWHM value of 0.1337 while the size of $\mathrm{TiO} 2$ crystal with $\mathrm{Zn}$ electrodeposition is around $50.65 \mathrm{~nm}$ with a FWHM value of 0.1671 . This shows that the electrodeposition process of $\mathrm{Zn}$ can affect the size of $\mathrm{TiO} 2$ crystals in $\mathrm{TiO} 2$ thin films. The small crystal size can mean increased surface area of $\mathrm{TiO} 2$ to absorb dyes. The more dye absorbed, the better the absorption of sunlight so that it can increase the efficiency of the DSSC produced.

Table 1. Results of XRD TiO2 Data Interpretation

\begin{tabular}{|l|l|l|l|l|}
\hline No & $2 \theta\left(^{\circ}\right)$ & $\mathrm{d}(\mathrm{A})$ & $\mathrm{I} / \mathrm{I} 0$ & $\begin{array}{l}\text { Crystal } \\
\text { phase }\end{array}$ \\
\hline 1 & 25,33 & 3,5128 & 1000 & Anatase \\
\hline 2 & 37,83 & 2,3764 & 121,97 & Anatase \\
\hline
\end{tabular}

\begin{tabular}{|l|l|l|l|l|}
\hline 3 & 48,06 & 1,8915 & 140,44 & Anatase \\
\hline 4 & 53,92 & 1,6990 & 71,46 & Anatase \\
\hline
\end{tabular}

Table 2. Results of XRD TiO2 Data Interpretation with Zn electrodeposition

\begin{tabular}{|l|l|l|l|l|}
\hline No & $2 \theta\left(^{\circ}\right)$ & $\mathrm{d}(\mathrm{A})$ & $\mathrm{I} / \mathrm{I} 0$ & Crystal fase \\
\hline 1 & 25,27 & 3,5221 & 1000 & Anatase \\
\hline 2 & 37,76 & 2,3808 & 146,99 & Anatase \\
\hline 3 & 47,99 & 1,8943 & 162,30 & Anatase \\
\hline 4 & 53,85 & 1,7012 & 99,40 & Anatase \\
\hline 5 & 55,02 & 1,6677 & 87,18 & Anatase \\
\hline
\end{tabular}

SEM-EDS analysis was carried out to determine surface morphology and identify $\mathrm{Zn}$ metals on $\mathrm{TiO} 2-\mathrm{Zn}$ surfaces. The SEM results show that the electrodeposition of $\mathrm{Zn}$ forms a lump on the surface of the $\mathrm{TiO} 2$ layer. $\mathrm{Zn}$ clumps on this surface will form a metal contact that serves to prevent the recombination of electrons in the dye with electrolytes and accelerate the flow of electrons toward the TCO glass because it has high conductivity. The presence of $\mathrm{Zn}$ metal was confirmed by the EDS instrument as shown in the figure with a $\mathrm{Zn}$ percentage of $4.72 \%$. The EDS results showed that the composition of the material contained in the layer was $35.16 \% \mathrm{O}, 60.11 \% \mathrm{Ti}$ and $4.72 \%$ Zn.

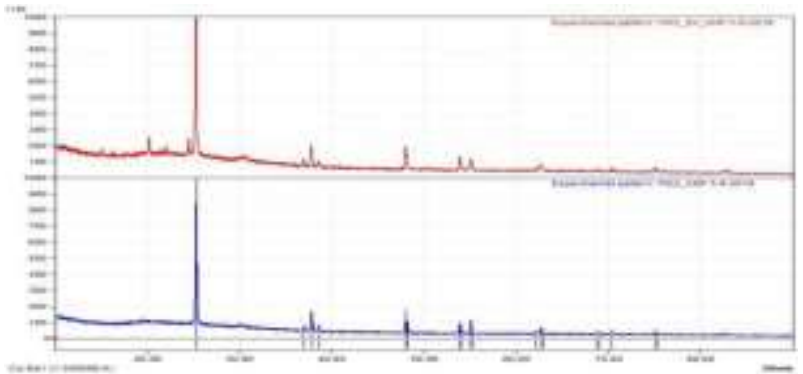

Figure 3. Diffractrogrammed XRD analysis results for $\mathrm{TiO} 2$ without electrodeposition $\mathrm{Zn}$ and with $\mathrm{Zn}(\mathrm{Zn}-\mathrm{TiO} 2)$ electrodeposition. 


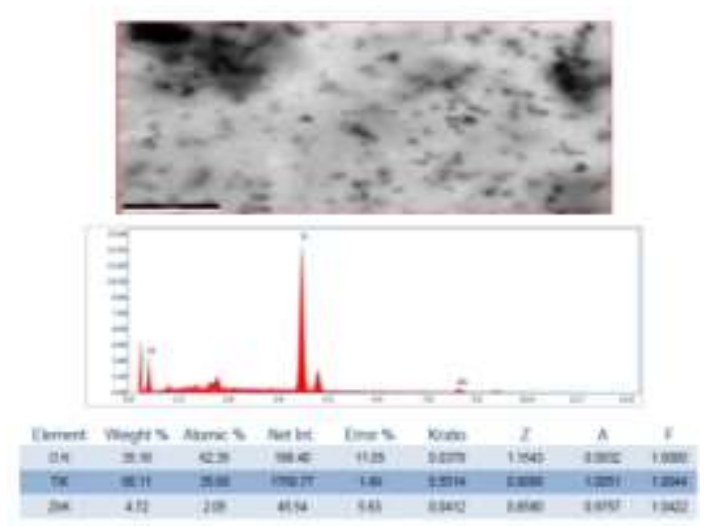

Figure 4. SEM-EDS test results

\subsection{Characterization of dyes}

The dyes used in this study were jengkol peel extract, resident fruit, mangosteen peel and grape skin. In the extract of these dyes there are known compounds that can form dyes, namely anthocyanin. Anthocyanins are compounds that can form dyes from red to blue
a. Mangostees skin, $\square \max =515 \mathrm{~nm}$

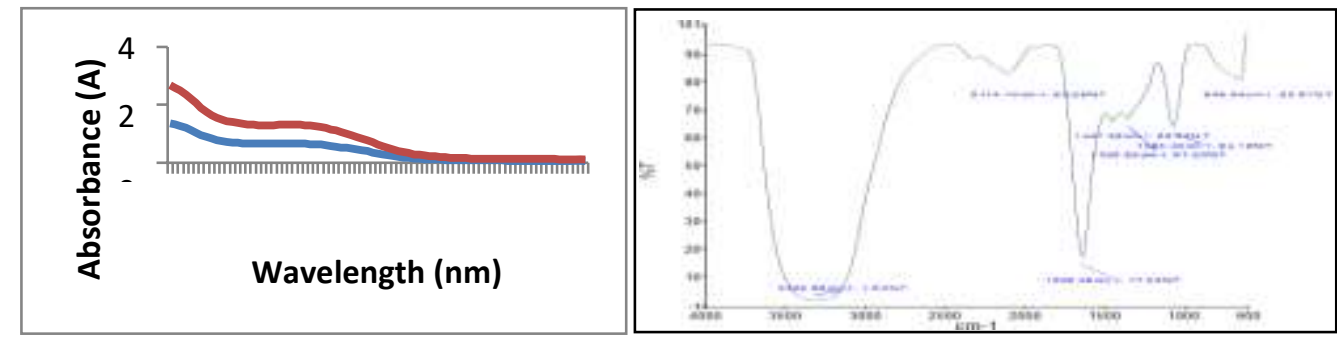

\section{\& 导}

b. Jengkol skin, $\square \max =515 \mathrm{~nm} \square 520 \mathrm{~nm}$

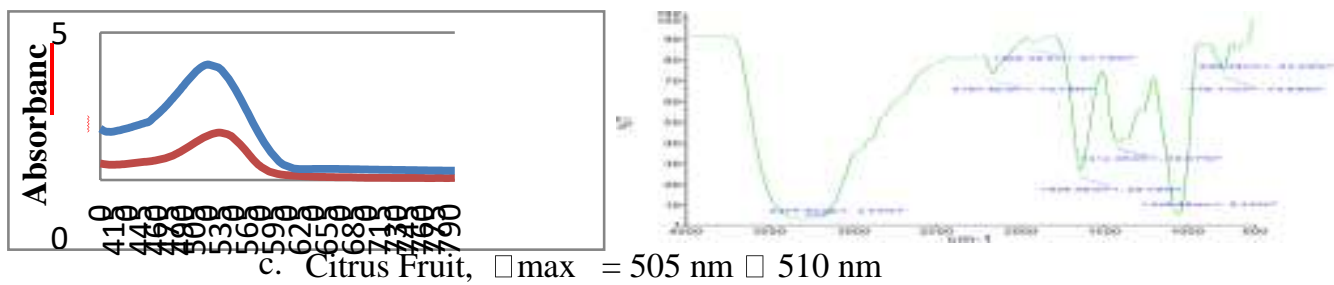




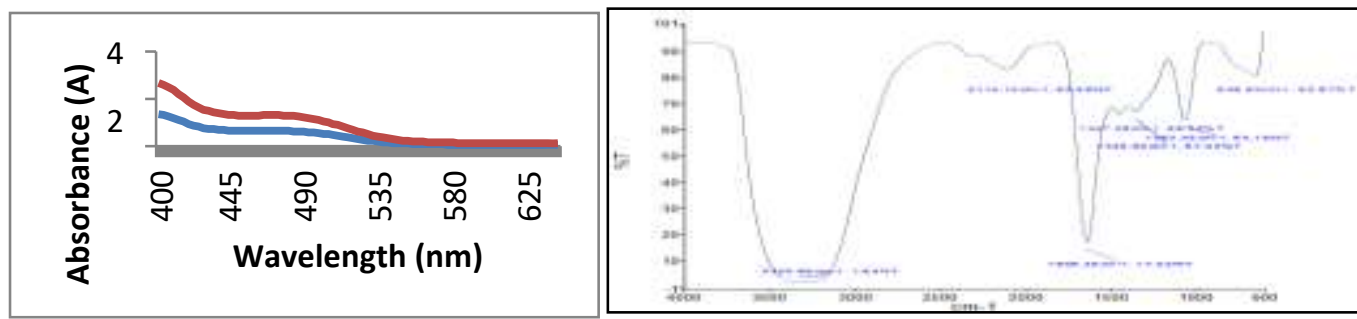

d. Grape skin, $\square \max =525 \mathrm{~nm} \square 535 \mathrm{~nm}$
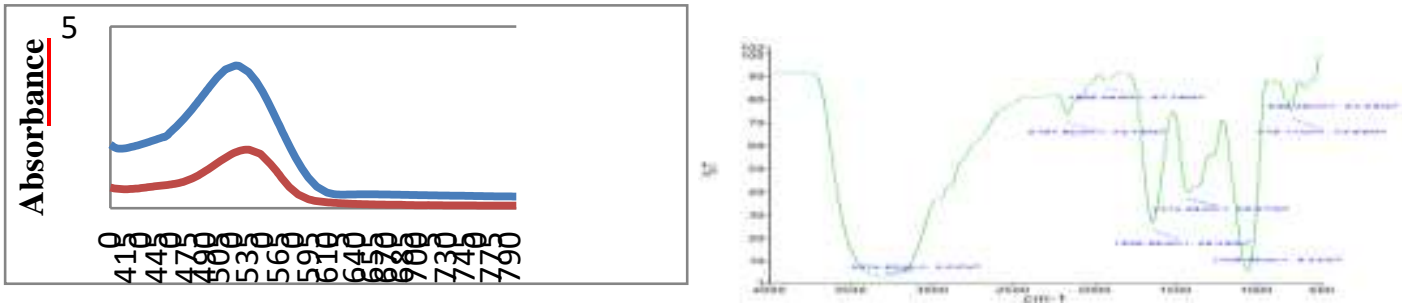

Figure 5. Absorbance of various pigmented salicylic acid co-pigmented: (a) mangosteen skin, (b) jengkol skin, (c). sit and fruit, and (d) grape skin.

The UV-Vis test results showed that the dyestuff extract had a different maximum wavelength ( $\lambda$ max). Jengkol peel extract has $\lambda$ maks which is $515 \mathrm{~nm}$, the resident fruit is 505 $\mathrm{nm}$, mangosteen peel is $515 \mathrm{~nm}$, and grape skin is $525 \mathrm{~nm}$. Based on these data, the skin of grapes has the highest $\lambda \max$ so that the absorption of sunlight by the skin of grapes is better than other extracts of dyes. Based on UVVis test results it is also known that the extract of grape skin has an absorption width of around $450 \mathrm{~nm}-600 \mathrm{~nm}$ while the dye extract of jengkol skin, resident fruit, and mangosteen peel is $475 \mathrm{~nm}-600 \mathrm{~nm}$. A wide absorption of large absorption has a better absorption of sunlight.

The results of UV-Vis extracts of dyes that have been copigmented with salicylic acid have changed at $\lambda \max$. Dyestuff extract from jengkol skin, resident fruit and grape skin had a batochromic effect with $\lambda \max$ to $520 \mathrm{~nm}, 510$ $\mathrm{nm}$, and $535 \mathrm{~nm}$ respectively while mangosteen peel extract experienced hyperchromic effects with increased absorption at $515 \mathrm{~nm} \lambda \max$. Copigmentation showed an increase in absorption intensity at a greater wavelength so that the absorption of light would increase and produce a positive effect for DSSC.

\subsection{Calculation of Efficiency}

DSSC performance measurement can be done by measuring the efficiency of the assembled DSSC. DSSC efficiency measurements are carried out with the help of UV lamps with 24 watts of power and a multimeter to measure the voltage and resistance produced. The current from the assembled DSSC can be calculated by the equation $\mathrm{V}=\mathrm{I}$.R. Where $\mathrm{V}$ is the voltage generated in Volt, $\mathrm{R}$ is the resistance in DSSC with unit dengan (ohms) and $\mathrm{I}$ is the current flowing on DSSC. Efficiency measurements were carried out on DSSC with variations in voltage and time of electrodeposition and on the titanium dioxide layer without $\mathrm{Zn}$ electrodeposition to observe the effect of voltage and time on DSSC efficiency and determine the optimum electrodeposition conditions that produce maximum DSSC efficiency.

$\mathrm{Zn}$ electrodeposition voltage variations are carried out using a fixed time of 10 seconds. Based on these data the electrodeposition voltage of $1 \mathrm{~V}$ produces solar cells with an efficiency of $4.14 \%$ while the results of DSSC efficiency measurements using titanium dioxide without $\mathrm{Zn}$ electrodeposition produce an efficiency of $0.8 \%$. The increase in DSSC efficiency by using Zn electrodeposition occurs because the formation of the $\mathrm{ZnO}$ layer on the surface acts as a barrier layer to reduce the recombination process between the injected electrons and the redox pair on the electrolyte. $\mathrm{ZnO}$ formation can reduce electron recombination because $\mathrm{ZnO}$ provides additional electron traps (Mozaffari et al., 2015). The increase in efficiency

also occurs due to the decrease in the size of the $\mathrm{TiO} 2$ crystals after the $\mathrm{Zn}$ electrodeposition process which causes an increase in the surface area that absorbs the dye. The efficiency of DSSC using dye extracts and Zn electrodeposition can be observed in Table 3 . 
Table 3. Efficiency of DSSC electrodeposition of $\mathrm{Zn}$ on $\mathrm{TiO} 2$ and dye extract from natural ingredients

\begin{tabular}{|c|c|c|c|c|}
\hline No & Dye & $\begin{array}{c}\text { The voltage } \\
\text { produced (V) }\end{array}$ & $\begin{array}{c}\text { Current } \\
\text { generated (A) }\end{array}$ & $\begin{array}{c}\text { Efficiency } \\
(\%)\end{array}$ \\
\hline 1 & Jengkol skin & 0,3025 & $\begin{array}{l}1,0016 \times 10- \\
4\end{array}$ & 1,2625 \\
\hline 2 & Citrus fruit & 0,3888 & $1,271 \times 10-4$ & $2,0584 \%$ \\
\hline 3 & Mangosteen & 0,1916 & $6,141 \times 10-5$ & $0,4903 \%$ \\
& skin & & & \\
\hline 4 & Grape skins & 0,574 & $2,1498 \times 10-$ & $5,1416 \%$ \\
& & & 4 & \\
\hline
\end{tabular}

The data in the table shows that the DSSC efficiency sequentially from lowest to highest starts from DSSC that uses dyes from mangosteen peel, jengkol skin, resident fruit, and grape skin. Grape skins produce the highest efficiency DSSC. The highest efficiency is due to the skin of grapes that have been copigmented with salicylic acid has the highest absorption. The co-pigmented grape skin has a maximum wavelength of $535 \mathrm{~nm}$ which is the highest compared to other dyes. This maximum wavelength indicates that the compound anthocyanin and salicylic acid require low energy to excite electrons. Electrons that are excited from the conduction band to the valence band of grape dye extract will flow into $\mathrm{TiO} 2$. The lower the energy needed for the electron excitation process, the more electrons will be transmitted to $\mathrm{TiO} 2$ and to the outer circuit of DSSC.

\section{CONCLUSION}

The decrease in crystal size will cause an increase in the surface area of $\mathrm{TiO} 2$ thereby increasing DSSC efficiency. The highest efficiency was obtained on DSSC by Zn electrodeposition in $\mathrm{TiO} 2$ layer using grape skin as a source of dyes.

\section{REFERENCES}

[1] Asy'ari, H., Jatmiko, \& Angga. (2012). Intensitas Cahaya Matahari terhadap Daya Keluaran Panel Sel Surya. Simposium Nasional RAPI XI FT UMS (pp. 52- 57). Surakarta: Universitas Muhammadiyah Surakarta.

[2] Castaneda-Ovando, A., Paez-Hernandez, E., Rodriguez,J. A., \& Galan-Vidal, C. A. 2009. Chemical studies of anthocyanins: A review. Food Chemistry, 113(4), 859-871.

[3] Chadijah, S., Dahlan, D., \& Harmadi, H. 2018. Pembuatan Counter Electrode Karbon Untuk Aplikasi Elektroda Dye-Sensitized Solar Cell
High efficiency on DSSC produced due to $\mathrm{Zn}$ electrodeposition. Based on the XRD electrodeposition $\mathrm{Zn}$ results in a decrease in the size of $\mathrm{TiO} 2$ crystals. The small size of $\mathrm{TiO} 2$ crystals can affect the efficiency of the DSSC produced. The size of $\mathrm{TiO} 2$ crystals that are nanometer in size and have an anatase phase have a large surface area so that they can accommodate a greater amount of dyes. The more dyes that are accommodated, the photon absorption increases and DSSC efficiency will also increase (Maulina, Hardeli \& Bahrizal, 2014).

(DSSC). Jurnal Ilmu Fisika | Universitas Andalas, 8(2), 78-86.

[4] Damayanti, R., Hardeli, \& Sanjaya, H. (2015). Preparation of Dye Sensitized Solar Cell (DSSC) Using Anthocyanin Extract From Purple Sweet. Jurnal Saintek, 6 (April), 148157.

[5] Hardeli, Zainul, R., \& Isara, L. P. 2019. Preparation of Dye Sensitized Solar Cell (DSSC) using anthocyanin color dyes from jengkol shell (Pithecellobium lobatum Benth.) by the gallate acid copigmentation. Journal of Physics: Conference Series, 1185(1).

[6] Hidayat, A. S., Rokhmat, M., \& Qurthobi, A. (2014). Pengaruh Suhu dan Kecepatan Putar Spin Coating terhadap Kinerja Sel surya Organik Berbahan Dasar TiO2. e-Proceeding of Engineering.1, pp. 497-510. Bandung: Universitas Telkom.

[7] John K, A., Naduvath, J., Mallick, S., Pledger, J. W., \& Philip, R. R. 2016. Electrochemical Synthesis of Novel Zn-Doped TiO2 Nanotube / $\mathrm{ZnO}$ Nanoflake Heterostructure with Enhanced 
DSSC Efficiency. Nano- Micro Letters. Springer Berlin Heidelberg.

[8] Kumara, M. S. W., \& Prajitno, G. (2012). Studi Awal Fabrikasi Dye Sensitized Solar Cell (DSSC) dengan Menggunakan Ekstraksi Daun Bayam (Amaranthus Hybridus L.) sbg Dye Sensitizer dengan Variasi Jarak Sumber Cahaya pada DSSC. Jurnal Fisika.

[9] Lestario, L.N., dan Andini, S. 2016. Kopigmentasi kuersetinapel ( pyrus malus ) terhadap stabilitas warna ekstrak buah duwet ( syzygium cumini )Pros. Konser Karya Ilm. 2, 37-42.

[10] Maulina, A. (2014). Preparasi Dye Sensitized Solar Cel Menggunakan Ekstrak Antosianin Kulit Buah Manggis (Gracinia Mangostana L). Jurnal Saintek, VI(2), 158- 167.

[11] Mozaffari, S. A., Ranjbar, M., Kouhestanian, E., Salar Amoli, H., \& Armanmehr, M. H. (2015). An investigation on the effect of electrodeposited nanostructured $\mathrm{ZnO}$ on the electron transfer process efficiency of $\mathrm{TiO} 2$ based DSSC. Materials Science in Semiconductor Processing, 40, 285-292.

[12] Nurfithri, M., Rokhmat, M. \& Handayani, I.P. 2016. Penumbuhan Partikel $\mathrm{Cu}$ menggunakan Fix Current Elctroplating dan Aplikasinya pada Solar Cell Berbahan Dasar TiO2. e-Proceeding of Engineering, 3(2): 2054- 2061.

[13] Prasetyowati, R. 2012. Sel Surya Berbasis Titania Sebagai Sumber Energi Listrik AlternatifPros. Semin. Nas. Penelitian, Pendidik. dan Penerapan MIPA, Fak. MIPA, Univ. Negeri Yogyakarta, 2 Juni 2012453 462.

[14] Prasetyowati, R. 2017. Studi Preparasi Dan Karakterisasi Sel Surya Berbasis Titania Melalui Penyisipan Logam Tembaga $(\mathrm{Cu})$ Dengan Berbagai Variasi Massa Pada Lapisan Aktif Titania. Jurnal Sains Dasar, 6(1), 1.

[15] Septina, W., Fajarisandi, D., \& Aditia, M. (2007). Pembuatan Prototipe Solar Cell Murah dengan Bahan Organik-Inorganik /Dye Sensitized Solar Cell/. Bandung ITB: ResearchGate.

[16] Sutrisno, H. (2010). Sel Fotovoltaik Generasi Ke-III: Pengembangan Sel Fotovoltaik Berbasis Titanium Dioksida. Prosiding Seminar Nasional Penelitian, Pendidikan, dan Penerapan MIPA (pp. 115-122). Yogyakarta: Universitas Negeri Yogyakarta. 